Document downloaded from:

http://hdl.handle.net/10251/158941

This paper must be cited as:

Fernandes, C.; Ferreira, J.; Peris-Ortiz, M. (2019). Open innovation: past, present and future trends. Journal of Organizational Change Management. 32(5):578-602.

https://doi.org/10.1108/JOCM-09-2018-0257

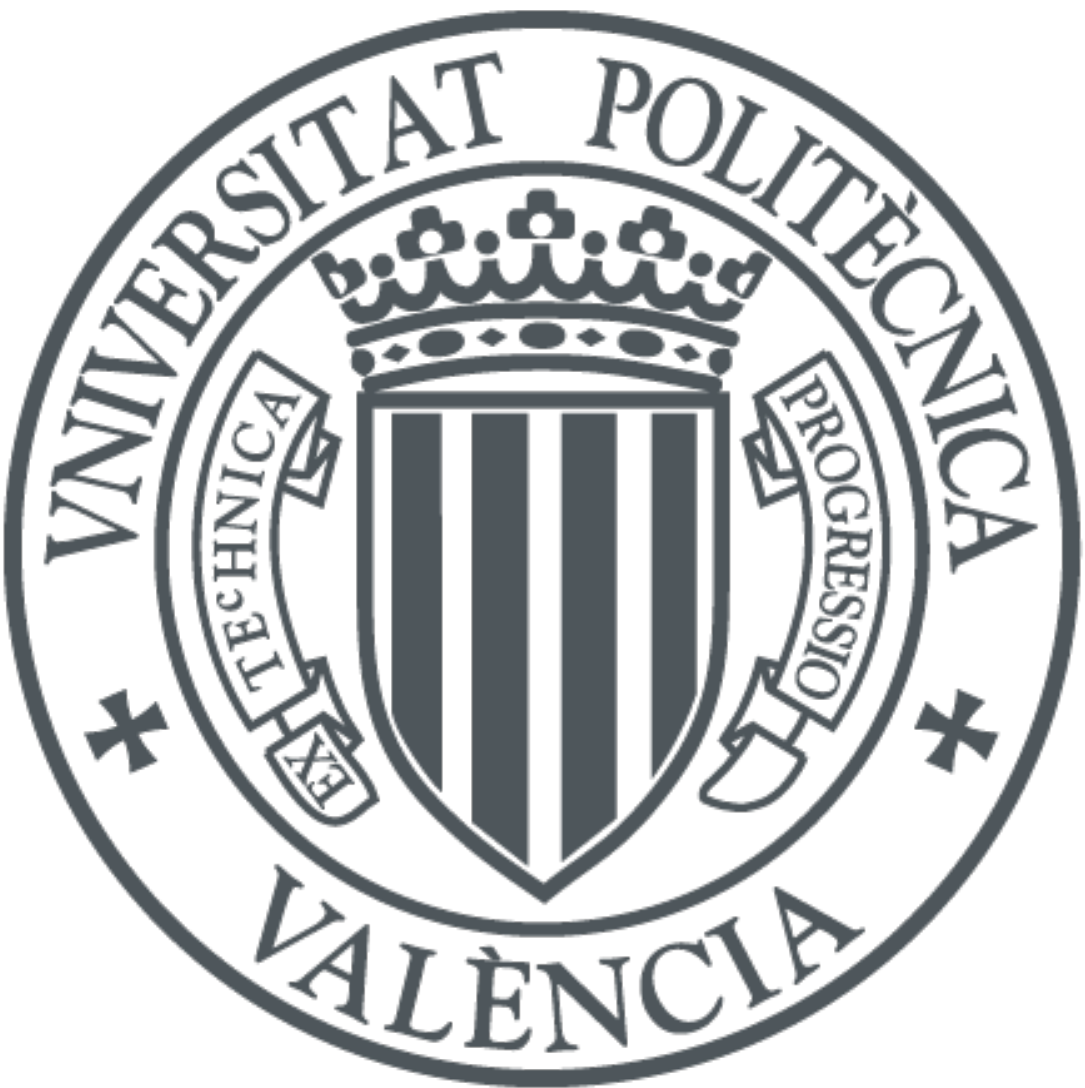

The final publication is available at

https://doi.org/10.1108/JOCM-09-2018-0257

Copyright Emerald

Additional Information 


\title{
Open Innovation: Past, Present and Future Trends
}

\begin{abstract}
The emergence of innovation has taken place under the deep effect of changes in the thinking about the vital importance of knowledge on the internal and external environments in which organisations cohabit. Therefore, and given this is a highly complex field of study, this research aims to map and analyse the intellectual knowledge held on open innovation. To this end, we carried out a bibliometric study with recourse to co-citations. Based on cluster and factorial analyses it is possible identify and classify the several theoretical perspectives on open innovation across six areas: Open Innovation concept, Open Innovation and Networks, Open Innovation and Knowledge, Open Innovation, and Innovation Spillovers, Open Innovation Management, and Open Innovation and Technology. Based upon this systematic literature review and the results obtained, we are able to suggest implications and recommendations for future research.
\end{abstract}




\section{Introduction}

Open innovation derives from a concept first proposed by Henry Chesbrough (2003). While the idea and discussions around some of the consequences (especially about R\&D based cooperation between companies) date back to the 1960s (Hartmann and Trott, 2009), the term originally referenced a paradigm that assumes that companies can and should make recourse to external ideas alongside those internally generated alongside internal and external approaches to markets to the extent that such companies strive to advance their technological evolution (Chesbrough, 2003).

More recently, the definition of open innovation has encapsulated this as a process of innovation distributed according to the flows of knowledge, deliberately managed on organisational frontiers, using mechanisms both of pecuniary and non-monetary types in accordance with the organisational business model (Chesbrough \& Bogers, 2014). According to Berthon et al. (2007), this definition has more recently recognised how open innovation does not only centre on the company: this also includes creative consumers and communities of innovative actors.

The boundaries between companies and their surrounding environments have become more permeable; innovation may easily get transferred inwards or outwards, between companies and companies as well as between companies and creative consumers thus resulting in impacts at the level of the consumer, the company, the industry and of the respective society (West, 2008; Bogers et al. 2017). The central idea underlying open innovation encapsulates how, in a world of broadly and widely distributed knowledge, companies may not trust entirely in their own research capacities and should also make recourse to purchasing or licensing processes or inventions (thus, patents) from other companies. Additionally, the internal inventions that do not get introduced into the business of any company may be exported beyond the company (for example, through licensing, joint ventures or spin-offs) (Chesbrough, 2003).

We may therefore interpret the open innovation paradigm as reaching beyond the simple usage of external sources of innovation, whether from clients, rival companies or academic institutions, and may instead extend both to a change in the usage, management and application of intellectual property and to the generation of intellectual property oriented towards technology and research. This perspective perceives open innovation as encouraging and systematically exploring a broad range of internal and external sources of innovative opportunities, the integration of this exploration into 
targeted resources and leveraging the opportunities thereby resulting through multiple channels (West \& Gallagher, 2006).

Furthermore, there is also the paradigm of close innovation that maintains that truly successful innovation requires control. A company should ensure control over the generation of its own ideas as well as their production, commercialisation, distribution, maintenance, financing and support. This perspective first emerged at the beginning of the $20^{\text {th }}$ century due to the fact that academic and governmental institutions were not then involved in the commercial application of science. There was not the time to expect the scientific community to get further involved in the more practical applications of science. There was similarly not enough time to await other companies beginning to produce some of the components that were necessary to the final product. These companies therefore became relatively self-sufficient with low levels of communication directed outwards, whether to other companies, universities, suppliers, clients, competitors or universities.

When companies do not capitalise on the knowledge that they have within their scope, then other companies shall end up doing so. Hence, innovations may stem from environments characterised by the closed innovation paradigm or by that of open innovation (Chesbrough, 2003).

The study of open innovation processes has become an intense field of research activities in recent years. Classified as an approach, this field of study seeks to explain how companies set about building innovation processes that start outside of any organisational scope.

The underlying motivations for such research arise out of the confluence of diverse factors: the importance of the concept and the recurrent references over the course of works published on the most diverse areas of the scientific field of management. Due to this fact, there is an increasing number of articles on this topic, which represents an additional challenge to undertaking a literature review, given the level of difficulty encountered in incorporating all these different contributions. However, this additional difficulty simultaneously represents both a stimulus and an opportunity: a stimulus as this expands the field of research and theoretical study while posing a challenge and an attractive opportunity as this opens up a broad field featuring different perspectives on the nature of open innovation.

Thus, the objective of our research is to provide interested parties with the means of grasping how the literature on open innovation has evolved over the course of time. In 
this way, we furthermore contribute towards a better understanding, scaling and positioning of this field of research. To this end, this study applies a combination of bibliometric techniques, such as citations, co-citations and social network analysis in order to map the scientific domain of open innovation. Currently, bibliometric analysis represents a methodology in effect on a global scale to evaluate the existing state of fields of research (Mutschke, Mayr, Schaer, \& Sure, 2011). This spans the application of quantitative and statistical analysis to publications such as articles and their respective citations and serving to evaluate the performance of research through returning data on all of the activities ongoing in a scientific field with summaries of this data generating a broad perspective on the research activities and impacts, especially as regards the researchers, journals, countries and universities (Hawkins, 1977; Osareh, 1996; Thomsom Reuters, 2008).

\section{Literature Review}

The White Paper (2001), produced by the National Commission on Entrepreneurship (NCOE), defends that the greatest contribution from entrepreneurship at the local level stems from innovation. From the 1980s onwards, there has been steady change in the vision of the traditional and linear model of innovation and correspondingly endowing this view with greater dynamism and interaction (Kline \& Rosenberg, 1986; Von Hippel, 1988). Currently, innovation receives widespread recognition as one of the main drivers of growth in an era designated the "age of knowledge" (Stough, 2003; Mention, 2011).

Thus, in an increasingly competitive global business environment, innovation stands out as an ever more critical factor for any company striving to attain a dominant position (Cheng et al., 2010) given its capacity to revitalise its competences (Hu and Hsu, 2008; Kaminski et al, 2008). Innovation furthermore serves as one of the key methods for adapting to the increasingly dynamic surrounding environments (Roberts \& Amit, 2003; Hua \& Wemmerlov, 2006; Doloreux \& Melancon, 2008), and as a process able to transform opportunities into practical utility (Tidd et al., 1997). The effective implementation of innovation has also gained rising recognition as synonymous with building sustainable competitive advantage and therefore also enhancing the performance of organisations (Koc \& Ceylan, 2007). 
Thus, in environments characterised by their rising levels of competitiveness, innovation proves a critical factor for companies striving either to attain dominant positions or to boost their profits (Hu \& Hsu, 2008; Kaminski et al., 2008). Various different authors maintain that innovation would seem to be the only means for companies to adapt to their increasingly dynamic surroundings (Roberts \& Amit, 2003; Hua \& Wmmerlov, 2006; Doloreux \& Melancon, 2008).

Through analysis of the introduction of new processes, products and ideas at the organisational level, we may measure the innovative capacities of companies (Hurley \& Hult, 1998). Innovation stems from the flexibility companies are able to attain through choosing different options and ways of satisfying consumer desires (Banbury \& Mitchell, 1995) through strategies underpinned by company resources and capacities that enable not only the meeting of those desires in the present but also into the future (Wernerfelt, 1984; Barney, 1991; Drazin \& Schoonhoven, 1996; Tushman \& O’Reilly, 1997; Souitaris, 2002; Hwang, 2004; Lemon \& Sahota, 2004).

The concept of open innovation typically incorporates the inputs and outputs of knowledge in terms of organisational capacities, with greater attention to flows of knowledge or the input dimension to open innovation - thus, recourse to sources of external knowledge to accelerate innovation (West et al., 2014). However, these flows of research findings tell us little about the role of individuals in open innovation. One exception comes with the study by Chatenier et al. (2010), who looked at the individual level competences that enable them to broker solutions for open innovation. More recently, Salter et al (2014) applied their attentions to the challenges of open innovation and the coping strategies of $R \& D$ professionals.

Another study considered how the openness of individuals as sources of external knowledge impacts on their performance in terms of the creation of ideas (Salter et al., 2015). Curiously, Dahlander et al. (2016) reported that individuals with external focuses are only more innovative (measured by patents) in conditions that place greater emphasis on these sources - raising additional questions as regards whether individuals influence the openness of companies. Ahn et al. (2017) also demonstrated how the characteristics of their CEOs (positive attitudes, business orientation, patience and level of education) might constitute an important factor in facilitating the occurrence of open innovation. Still more recently, Rangus and Černe (2017) confirmed how leadership does influence the tactics and openness of employees that, in turn, shapes their innovation based performance across both the individual and team levels. 


\section{Methodology and data}

Co-citation analysis provides a consensually based methodology for mapping in detail the relationships between the core ideas prevailing in any specific scientific field (Small, 1973) and serves to identify the fundamental scientific articles to that same field (Zitt \& Bassecoulard, 1994). Two articles attain the co-cited classification when they are jointly referenced by one or more other published articles (Smith, 1981), with the number of joint citations one means of summarising the literature existing on a particular area of knowledge while also identifying the most influential authors and displaying their respective interrelationships (White \& McCain, 1998). Various studies have demonstrated the validity of co-citation analysis for grasping the intellectual structure of fields of research (Di Guardo \& Harrigan, 2012).

\subsection{Methods}

Taking into consideration the objectives of this study, the first phase carried out the descriptive analysis of the articles resulting from the database search. We subsequently applied the bibliometric methodology of co-citation analysis, as detailed in the study by White and McCain (White \& McCain, 1998), in order to analyse the publications on open innovation. Thus, the number of times two articles or authors on open innovation get jointly cited within the universe of the publications identified is subject to analysis in order to identify the relationships among the citations and mapping the dominant approaches within the research field in question; open innovation.

To graphically portray the respective articles, we applied multidimensional scale analysis with the objective of producing a bi-dimensional figure that details all of the co-citation interconnections among the articles. This figure portrays points that when located at the source of the references represent articles with connections to articles that contain different approaches and with a fairly heterogeneous set of citations. Following multidimensional scaling, we applied hierarchical cluster analysis in order to group the interrelated articles into distinct groups in accordance with the figure resulting from the multidimensional scaling of the exposure of the groups.

Finally, we applied factorial analysis through the principal components method and with Varimax rotation so as to obtain additional information regarding the research 
existing on open innovation, specifically to determine just which articles share mutual components and which articles hold the greatest weighting in terms of each of the above factors. In this methodology, the results obtained by the analytical procedures also indicate the importance relative to each of the resulting factors.

\subsection{Data}

We gathered our citation and co-citation data from the Science Citation Index Expanded (SCI-Expanded), Social Science Citation Index (SSCI), compiled by the online Thomson/Reuters-ISI database that contains many thousands of academic publications and bibliographic information about their authors, affiliations and citations. The study searched the Web of Science ${ }^{T M}$ Core Collection database for articles published in journals falling into the management and business categories and published up to and including 2016 with the search term of "open innovation" in their titles, keywords or article abstracts.

This search returned a total of 1,092 articles with publication dates ranging between 2003 ( 2 articles) and 2016 (254 articles), cited 22,558 times with an average of 20.6 citations per article and citing a total of 10,548 references. Figure 1 presents the evolution in the articles published and their citations per year and correspondingly detailing how 2005 saw the fewest publications on this field that has experienced solid growth in the post-2010 period. The average year of article publication was 2013.2, reflecting the presence of an only very recently founded scientific field. In terms of the number of citations per year, there has been exponential growth with 723 citations in 2010 rising to 4,786 in 2016. 


\section{Figure 1 - Number of articles and citations by year}
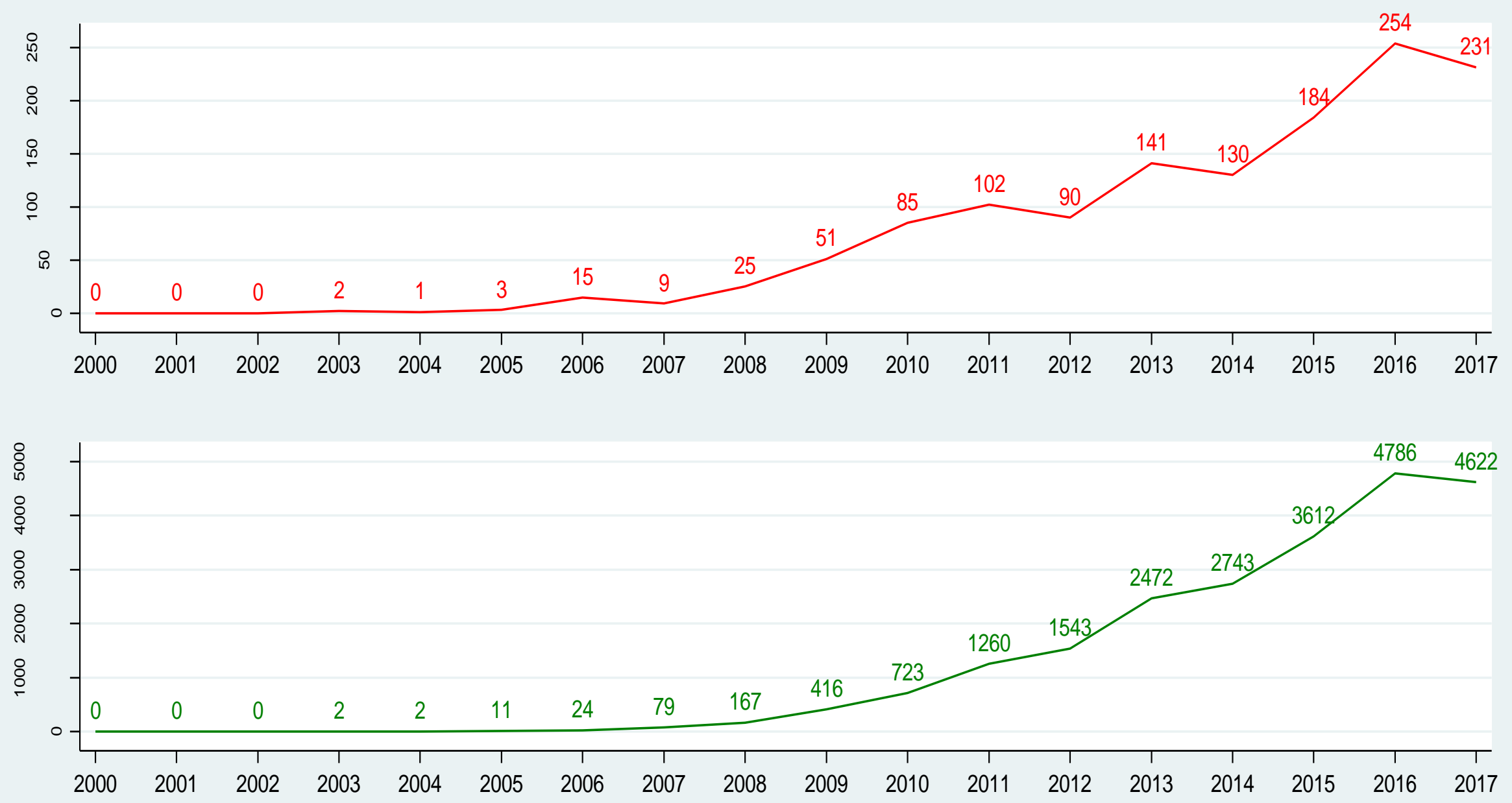
As regards the articles in themselves, the five receiving the largest number of citations respectively are:

1. Chesbrough, H. W. (2003). The era of open innovation. MIT Sloan Management Review, 44(3), 35-41. (784 citations)

2. Dahlander, L., \& Gann, D. M. (2010). How open is innovation? Research Policy, 39(6), 699-709. (547 citations)

3. Chesbrough, H. W., \& Crowther, A. K. (2006). Beyond high tech: early adopters of open innovation in other industries. $R \& D$ Management, 36(3), 229-236. (490 citations)

4. van de Vrande, V., de Jong, J. P. J., Vanhaverbeke, W., \& de Rochemont, M. (2009). Open innovation in SMEs: Trends, motives and management challenges. Technovation, 29(6-7), 423-437. (433 citations)

5. Enkel, E., Gassmann, O., \& Chesbrough, H. W. (2009). Open R \& D and open innovation: exploring the phenomenon. R\&D Management, 39(4), 311-316. (310 citations)

Figure 2 displays both the ten journals with the largest number of articles published on this field and the ten with the largest number of citations. The journals registering the largest number of publications are $R \& D$ Management (59 articles), International Journal of Technology Management (46 articles) and Research Policy (42 articles). As regards the citation numbers, the journals with the greatest frequency are $R \& D$ Management (3,677 citations), Research Policy (2,784 citations) and Technovation (2,219 citations). 
Figure 2 - Distribution of articles and total citations by journal
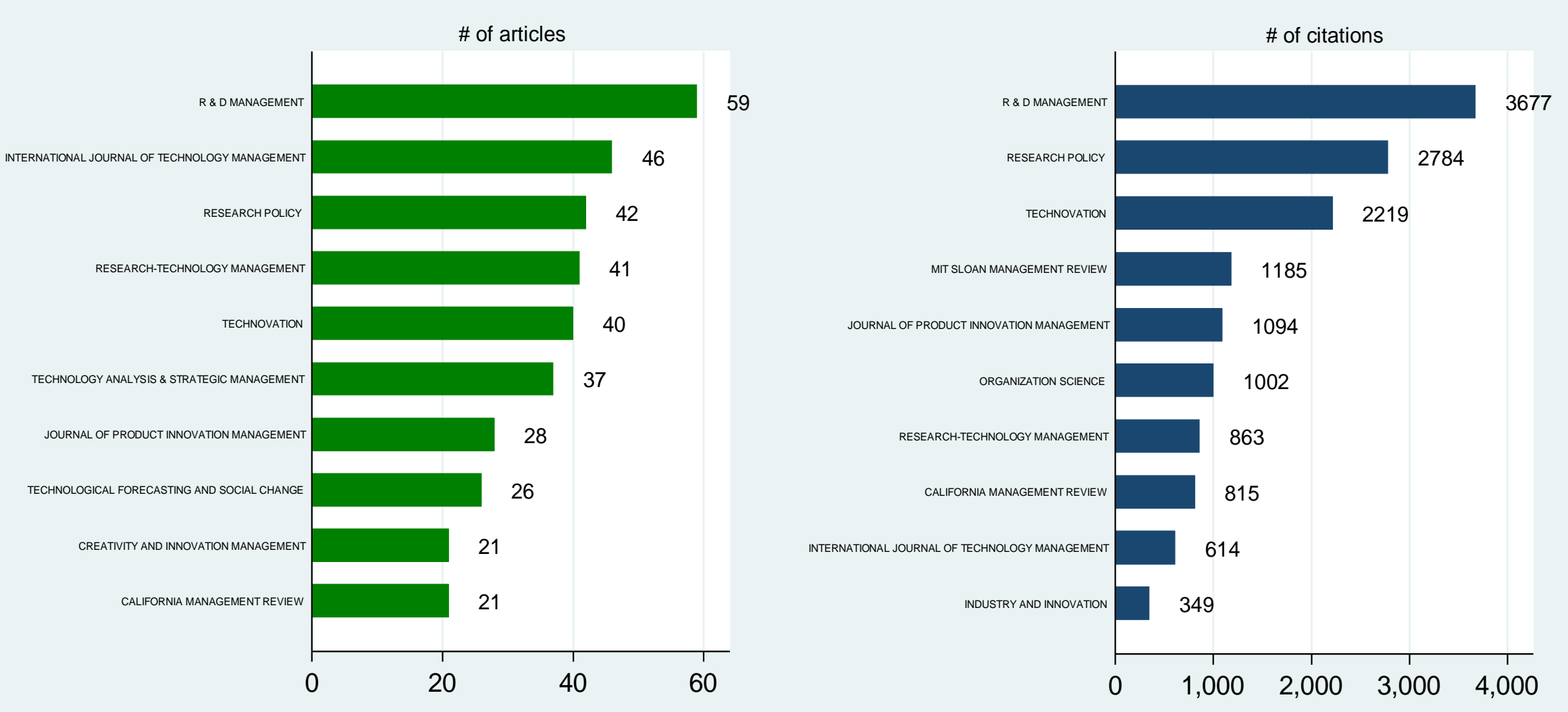
Following the search that returned 1,092 articles, we necessarily had to establish criteria for defining those articles that form the foundation of analysis in order to meet the objectives of our study. According to criteria of relevance, which narrows down the set of articles while taking into account how the inclusion of a large number of references contributes towards enriching the subsequent analytical stages, we selected the 100 most cited articles as the point of departure for the subsequent analysis. These articles contained a minimum of 50 citations apiece.

The distribution of these 100 articles by journal reveals how $R \& D$ Management once again contains the largest number of articles and citations (22 articles; 3,170 citations) followed by Research Policy (15 articles; 2,212 citations) and Technovation (13 articles, 1,723 citations). 
Figure 3 - Distribution of articles and citations by journal (100 articles included in analysis)
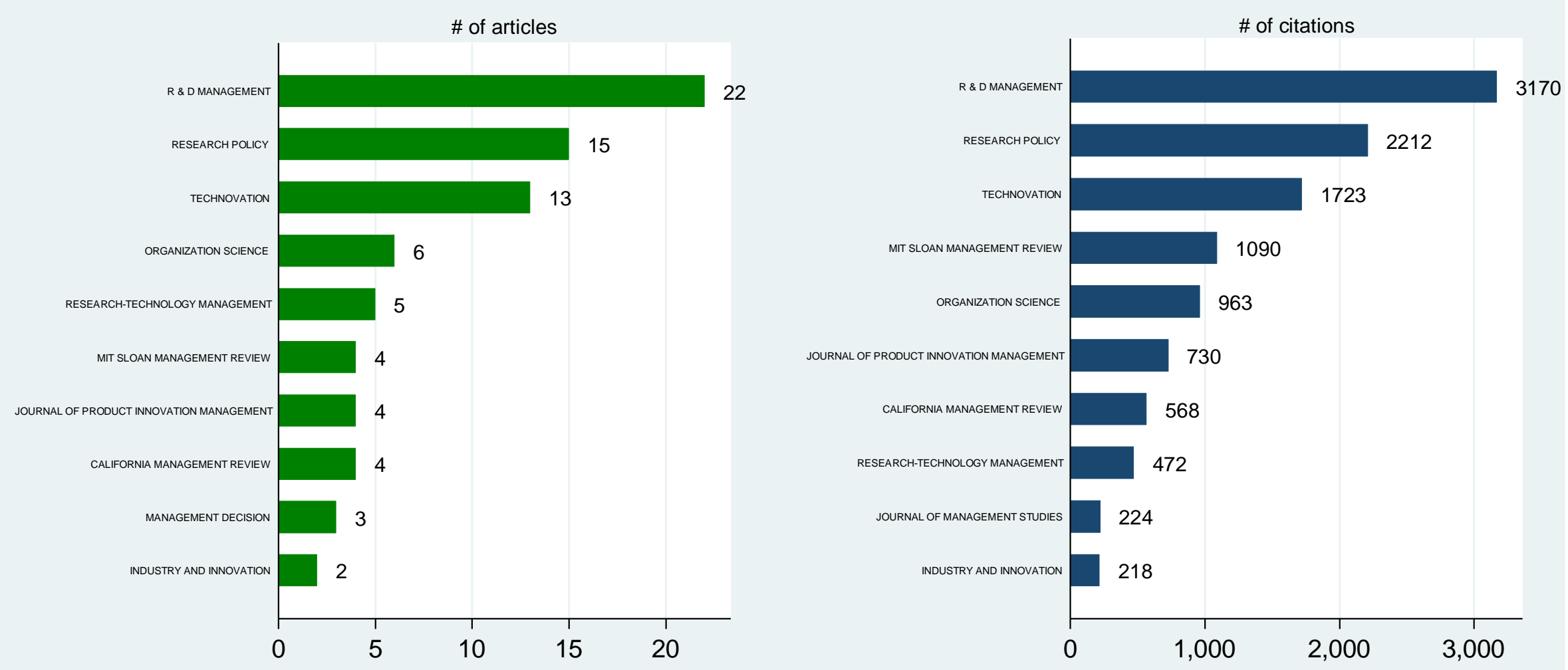


\section{Results}

4.1 Multidimensional scaling and cluster analysis

Multidimensional scaling (MDS) served as the method for generating a map with the objective of analysing the relationship between the articles, identifying the dimensions that best explain both their mutual similarities and their differences. Secondly, we applied cluster analysis so as to identify homogenous groups of articles. Finally, we made recourse to factorial analysis to identify the articles making up each factor and their respective level of contribution through the factorial weightings within each paradigm.

Figure 4 presents the bi-dimensional map of the articles returned by the multidimensional analysis procedure and applying the data from the co-citation matrix and the ALSCAL routines from the statistical IBM SPSS 24.0 for Windows program. This provides a list of articles, numbered in accordance with their ranking in terms of the number of citations contained (Table 2). The adjustment indexes (Kruskal's Stress $=0.02$ and $\mathrm{RSQ}=0.98$ ) report results demonstrating that this mapping process provides a very good approximation of reality. This grouping of the articles, as detailed in figure 4, by multidimensional scaling took place through cluster analysis based upon the hierarchical method of Ward. We list the articles included in each one of the resulting groups in Table 2 in the Appendix.

Despite, in keeping with dimensional scaling, the construction of the axes only being arbitrary, the overall positioning of the articles in the map endows significance on the

axes. 


\section{Figure 4 - Multidimensional Scaling and Cluster Analysis}

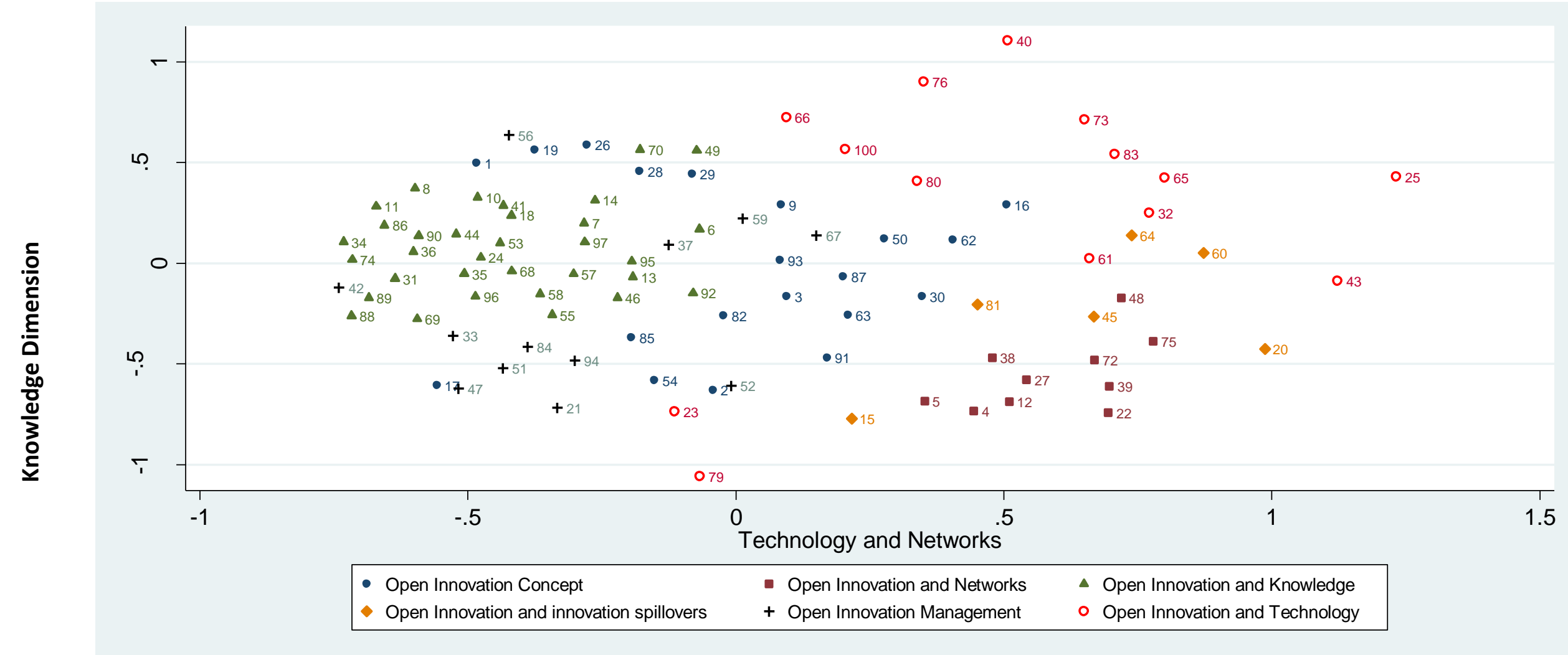


Factorial analysis aims to identify the articles making up each factor and discovering the influence each holds over the conceptual approaches through their respective factorial weightings. This analysis involved recourse to Varimax rotation in keeping with the example set by previous studies. In turn, the data analysed derived from the co-citation matrix.

In keeping with the factorial analysis results, we include an article in a particular trend whenever its factorial weighting is greater than or equal to 0.4 and having made a highly relevant contribution to the correspondingly paradigm whenever its factorial weighting equals or exceeds 0.7 .

Table 1 sets out the factorial analysis results. Based on the Scree Plot, we may report that six factors explain $42.8 \%$ of the variance. A proportion of the references return factorial weightings of over 0.7 , corroborating the importance of these works within the scope of their associated paradigms. We would also observe how some works attain a factorial weighting of over 0.4 in more than one factor and may correspondingly class as mediators among the paradigms and the potential bonds formed among the paradigms.

Table 1 - Factor Analysis (rotated factor loadings)

\begin{tabular}{|c|c|c|c|c|c|c|}
\hline \multirow[b]{2}{*}{ Article } & \multicolumn{6}{|c|}{ Component } \\
\hline & $\begin{array}{c}\text { Open } \\
\text { Innovation } \\
\text { Concept }\end{array}$ & $\begin{array}{c}\text { Open } \\
\text { Innovation } \\
\text { and } \\
\text { Knowledge }\end{array}$ & $\begin{array}{c}\text { Open } \\
\text { Innovation } \\
\text { and } \\
\text { Innovation } \\
\text { Spillovers }\end{array}$ & $\begin{array}{c}\text { Open } \\
\text { Innovation } \\
\text { and } \\
\text { Technology }\end{array}$ & $\begin{array}{c}\text { Open } \\
\text { Innovation } \\
\text { Management }\end{array}$ & $\begin{array}{c}\text { Open } \\
\text { Innovation } \\
\text { and Networks }\end{array}$ \\
\hline 2 & 0.71 & 0.35 & 0.13 & 0.29 & 0.05 & 0.01 \\
\hline 89 & 0.70 & 0.23 & -0.08 & -0.04 & 0.14 & 0.08 \\
\hline 6 & 0.70 & 0.35 & 0.13 & 0.09 & 0.08 & -0.04 \\
\hline 4 & 0.69 & 0.42 & 0.03 & 0.02 & 0.09 & 0.04 \\
\hline 36 & 0.67 & 0.34 & -0.03 & -0.03 & 0.15 & 0.04 \\
\hline 9 & 0.64 & 0.32 & 0.01 & 0.02 & 0.08 & 0.13 \\
\hline 88 & 0.63 & 0.20 & -0.05 & -0.01 & 0.04 & -0.05 \\
\hline 91 & 0.63 & 0.24 & 0.20 & 0.06 & -0.05 & -0.11 \\
\hline 46 & 0.62 & 0.18 & -0.10 & -0.05 & 0.00 & 0.09 \\
\hline 56 & 0.60 & 0.50 & 0.00 & -0.01 & 0.00 & 0.13 \\
\hline 39 & 0.60 & 0.30 & 0.04 & -0.09 & 0.00 & -0.06 \\
\hline 40 & 0.58 & 0.50 & 0.03 & -0.14 & 0.04 & -0.03 \\
\hline 7 & 0.58 & 0.42 & 0.08 & 0.03 & 0.06 & -0.10 \\
\hline 54 & 0.57 & -0.10 & -0.14 & 0.28 & 0.01 & 0.04 \\
\hline 41 & 0.55 & 0.12 & -0.02 & 0.09 & 0.02 & 0.23 \\
\hline 84 & 0.55 & 0.01 & -0.12 & 0.19 & 0.02 & 0.05 \\
\hline 5 & 0.54 & 0.41 & 0.14 & 0.18 & -0.05 & -0.05 \\
\hline 94 & 0.53 & 0.46 & 0.06 & 0.16 & 0.04 & -0.08 \\
\hline 45 & 0.53 & 0.39 & 0.05 & 0.07 & -0.01 & -0.09 \\
\hline 86 & 0.52 & 0.46 & 0.03 & -0.12 & 0.09 & -0.03 \\
\hline
\end{tabular}




\begin{tabular}{|c|c|c|c|c|c|c|}
\hline 60 & 0.52 & 0.44 & 0.01 & 0.11 & -0.06 & -0.03 \\
\hline 38 & 0.51 & 0.16 & -0.02 & 0.08 & 0.07 & -0.11 \\
\hline 48 & 0.50 & 0.45 & 0.06 & 0.04 & -0.03 & -0.01 \\
\hline 93 & 0.50 & 0.03 & -0.10 & 0.06 & 0.00 & 0.01 \\
\hline 24 & 0.49 & 0.44 & 0.10 & 0.05 & 0.01 & -0.09 \\
\hline 96 & 0.48 & 0.43 & 0.01 & 0.02 & 0.01 & 0.21 \\
\hline 59 & 0.47 & -0.07 & -0.04 & -0.09 & -0.06 & 0.24 \\
\hline 50 & 0.39 & -0.05 & -0.10 & -0.02 & 0.05 & 0.05 \\
\hline 61 & 0.37 & 0.20 & -0.02 & 0.13 & 0.07 & 0.03 \\
\hline 90 & 0.34 & -0.02 & 0.22 & 0.31 & 0.01 & -0.14 \\
\hline 69 & 0.34 & 0.08 & -0.03 & 0.17 & -0.05 & 0.04 \\
\hline 85 & 0.33 & 0.24 & -0.09 & 0.08 & 0.04 & 0.00 \\
\hline 55 & 0.31 & -0.03 & -0.04 & -0.09 & 0.00 & 0.16 \\
\hline 100 & 0.30 & 0.29 & 0.12 & 0.23 & -0.01 & -0.03 \\
\hline 33 & 0.27 & 0.16 & 0.07 & 0.22 & -0.01 & -0.03 \\
\hline 27 & 0.25 & -0.02 & -0.06 & 0.06 & -0.02 & 0.13 \\
\hline 64 & 0.18 & 0.11 & 0.03 & 0.03 & -0.07 & -0.11 \\
\hline 44 & -0.07 & -0.06 & -0.06 & -0.06 & -0.04 & -0.06 \\
\hline 30 & -0.07 & -0.06 & -0.06 & -0.06 & -0.04 & -0.06 \\
\hline 17 & 0.28 & 0.69 & 0.03 & 0.14 & 0.08 & 0.04 \\
\hline 14 & 0.30 & 0.67 & 0.09 & 0.09 & 0.02 & 0.03 \\
\hline 3 & 0.46 & 0.67 & 0.03 & 0.06 & 0.04 & 0.00 \\
\hline 18 & 0.40 & 0.63 & -0.03 & -0.05 & 0.02 & -0.03 \\
\hline 58 & 0.26 & 0.57 & -0.02 & 0.10 & 0.00 & 0.11 \\
\hline 13 & 0.19 & 0.57 & 0.08 & 0.36 & 0.01 & 0.06 \\
\hline 70 & 0.16 & 0.54 & -0.10 & -0.06 & -0.06 & -0.01 \\
\hline 75 & 0.46 & 0.52 & -0.08 & -0.14 & 0.01 & -0.02 \\
\hline 20 & 0.23 & 0.49 & 0.02 & 0.12 & 0.10 & 0.09 \\
\hline 71 & 0.01 & 0.49 & -0.06 & -0.09 & -0.06 & -0.01 \\
\hline 95 & 0.42 & 0.48 & -0.11 & -0.03 & 0.09 & 0.09 \\
\hline 15 & 0.27 & 0.42 & 0.01 & -0.03 & -0.03 & -0.10 \\
\hline 52 & 0.10 & 0.42 & -0.01 & -0.07 & -0.09 & -0.11 \\
\hline 1 & 0.10 & 0.42 & 0.04 & 0.15 & 0.05 & 0.04 \\
\hline 34 & 0.06 & 0.38 & -0.01 & 0.05 & 0.02 & 0.03 \\
\hline 25 & 0.05 & 0.36 & 0.00 & 0.16 & -0.01 & 0.02 \\
\hline 87 & 0.13 & 0.35 & 0.16 & 0.23 & -0.03 & 0.05 \\
\hline 31 & 0.10 & 0.31 & -0.01 & 0.09 & -0.02 & 0.14 \\
\hline 82 & 0.28 & 0.31 & 0.00 & 0.04 & -0.07 & -0.08 \\
\hline 23 & 0.02 & 0.29 & -0.01 & 0.07 & 0.04 & -0.07 \\
\hline 57 & 0.13 & 0.22 & -0.01 & 0.01 & 0.03 & -0.10 \\
\hline 29 & 0.04 & 0.22 & -0.03 & 0.04 & 0.09 & 0.13 \\
\hline 77 & -0.01 & -0.10 & -0.06 & -0.04 & -0.08 & -0.03 \\
\hline 37 & -0.07 & 0.08 & -0.04 & 0.02 & -0.06 & 0.03 \\
\hline 47 & -0.06 & -0.08 & -0.01 & -0.03 & -0.04 & -0.08 \\
\hline 73 & -0.01 & -0.05 & 0.76 & 0.00 & 0.00 & -0.02 \\
\hline 42 & 0.03 & 0.12 & 0.74 & 0.07 & -0.01 & 0.03 \\
\hline 19 & 0.01 & -0.02 & 0.69 & 0.12 & 0.01 & 0.00 \\
\hline 28 & -0.06 & -0.05 & 0.67 & -0.03 & 0.01 & -0.01 \\
\hline 12 & -0.06 & 0.21 & 0.62 & 0.09 & 0.01 & 0.04 \\
\hline 76 & -0.06 & -0.07 & 0.60 & -0.11 & 0.00 & 0.00 \\
\hline 11 & 0.09 & -0.10 & 0.51 & 0.31 & -0.04 & -0.06 \\
\hline 43 & -0.04 & -0.03 & 0.42 & 0.07 & 0.01 & -0.04 \\
\hline 51 & -0.02 & 0.03 & 0.36 & -0.09 & -0.01 & 0.06 \\
\hline 65 & 0.25 & 0.24 & 0.33 & 0.31 & -0.09 & -0.01 \\
\hline 32 & -0.03 & 0.04 & 0.29 & 0.20 & -0.03 & 0.00 \\
\hline 26 & -0.06 & -0.10 & 0.22 & 0.10 & -0.03 & -0.05 \\
\hline 66 & -0.05 & -0.05 & 0.13 & 0.08 & 0.01 & -0.02 \\
\hline 81 & 0.21 & -0.05 & -0.03 & 0.61 & -0.02 & -0.07 \\
\hline 16 & 0.14 & 0.38 & -0.02 & 0.54 & 0.03 & 0.07 \\
\hline 49 & 0.00 & 0.01 & 0.06 & 0.53 & 0.01 & -0.02 \\
\hline 35 & 0.13 & 0.23 & 0.30 & 0.51 & 0.02 & 0.09 \\
\hline
\end{tabular}




\begin{tabular}{ccccccc}
53 & 0.02 & 0.36 & 0.08 & 0.43 & 0.03 & 0.06 \\
92 & 0.34 & 0.21 & -0.02 & 0.37 & -0.10 & 0.05 \\
22 & 0.02 & 0.05 & 0.17 & 0.35 & 0.04 & 0.04 \\
10 & 0.07 & 0.25 & -0.02 & 0.35 & 0.09 & -0.01 \\
21 & -0.06 & 0.12 & 0.10 & 0.30 & -0.01 & 0.04 \\
62 & -0.03 & -0.08 & -0.02 & 0.17 & -0.03 & -0.05 \\
80 & 0.08 & 0.06 & -0.11 & 0.11 & -0.05 & 0.02 \\
97 & -0.01 & 0.03 & -0.09 & -0.05 & 0.84 & -0.01 \\
72 & -0.01 & 0.04 & 0.03 & 0.03 & 0.83 & 0.00 \\
98 & 0.21 & 0.07 & -0.12 & -0.09 & 0.82 & 0.10 \\
67 & -0.03 & -0.03 & -0.02 & -0.04 & -0.05 & 0.04 \\
78 & 0.20 & 0.03 & -0.01 & -0.05 & -0.09 & 0.89 \\
79 & 0.20 & 0.03 & -0.01 & -0.05 & -0.09 & 0.89 \\
63 & 0.07 & 0.03 & 0.03 & -0.03 & -0.04 & -0.12 \\
8 & -0.02 & 0.05 & -0.05 & 0.01 & -0.08 & -0.09 \\
68 & 0.00 & 0.08 & -0.02 & -0.08 & -0.02 & 0.09 \\
83 & -0.01 & -0.04 & -0.08 & 0.00 & -0.02 & -0.08 \\
99 & 0.06 & 0.02 & 0.01 & -0.07 & -0.08 & -0.08 \\
74 & -0.04 & -0.07 & -0.07 & -0.06 & -0.06 & -0.07 \\
\hline
\end{tabular}

Based upon the results of multidimensional scaling (cluster analysis) and factorial analysis, we were able to identify different research dimensions and patterns in the literature. Cluster analysis was performed based on Ward's hierarchical method, which allowed us to obtain homogeneous groups of articles (table in the appendix). We specifically encountered six clusters even while some contain mutual relationships: i) the open innovation concept; ii) open innovation and networks; iii) open innovation and knowledge; iv) open innovation and innovation spillovers; v) open innovation management; and vi) open innovation and technology.

\section{Cluster 1 ( $n=27$ articles): the Open Innovation Concept}

Globalisation broke with the linear model of innovation and opened up new opportunities and challenges, especially for companies located in peripheral regions and those only marginally innovative. According to the "open innovation" definition, innovation is not exclusively an intramural phenomenon and companies - whether through choice or need - cooperate among themselves with the objective of building on their innovative capacities (Chesbrough, 2003a). There thus emerges the need to propose the review and evaluation of the social science debate around the origins and nature of innovation in modern society. Three conceptual sub-sets concentrate the criticism and comments that specifically refer to sub-national or regional innovation systems (Christensen, Olesen, and Kjaer, 2005; Cooke, 2005). Currently, studies of open innovation tend to focus upon high-technology multinational entities. Idea competitions represent a promising tool for various open innovation based processes, especially for high-technology firms (Leimeister, Huber, Bretschneider, and Krcmar 
2009; Keupp \& Gassmann, 2009; Li, 2009). Despite the growing interest in open innovation, the discussion about this concept and its potential applications to the small and medium sized company (SME) sector falls beyond the scope of the conventional literature. However, given how arguments around the effects of company size on its innovation efficiency remain widely under study, approaching this question from the SME dimension is correspondingly worthwhile (Lee, Park, Yoon, \& Park, 2010; Stang et al. 2010; Enkel \& Gassmann, 2010).

Open innovation thus became one of the most important topics within the framework of innovation management. The open innovation process interrelates with the transition to open innovation as well as various open innovation practices. Open innovation provides a valuable concept to many companies and in equally numerous contexts (Huizingh, 2011; Baldwin \& von Hippel, 2011; Spithoven, Clarysse, \& Knockaert, 2011; Bianchi, Cavaliere, Chiaroni, Frattini, \& Chiesa, 2011; Rost, 2011; Mortara \& Minshall; 2011; Allarakhia \& Steven, 2011). Open innovation thus holds benefits for different innovation results and outcomes. For example, the sourcing of technology interlinks with the subsequently resulting innovation performance (Chesbrough, 2012; Parida, Westerberg, \& Frishammar, 2012; Drechsler \& Natter, 2012).

\section{Cluster $2(n=10$ articles): Open Innovation and Networks}

The concept of "vertical architecture" defines the purpose of a company and the extent to which it is open to its final and intermediate market; this describes the configurations of the transactional options over the length of the company's chain of value. A company may opt to make or acquire its inputs and transfer its outputs downstream or sell them. Permeable vertical architectures contain partially integrated facets alongside others partially open to the market along the respective chain of value. Enhanced permeability enables the most effective usage of resources and capacities, a better combination of capacities with the needs of the market and benchmarking for improving efficiency. Partial integration nurtures a more dynamic and open platform for innovation and that improves the strategic capacities through the interconnection of the key links in the chain of value. This permeable vertical architecture, accompanied by appropriate transfer pricing and incentive designs, facilitates the allocation of resources and guides the company's ongoing growth process (Jacobides \& Billinger, 2006). The networks of innovation may also serve to deal with changes in the surrounding technological environment and may act as a means for companies to swiftly adapt to changes in 
market conditions as well as strategic changes (Dittrich \& Duysters, 2007). In open innovation processes, beyond companies acquiring external technology, they begin to actively commercialise their own technological knowledge, which represents the opposite type of technology transaction. Deep interactions with the environment of a company contrast with traditionally closed approaches to innovation (Lichtenthaler, 2008). Open innovation enables companies to discover combinations of product characteristics that would otherwise be difficult to integrally visualise. However, when the partners have divergent objectives, open innovation limits the company capacity to establish the traditional technological trajectory for the product. The resolution of the trade-off between the benefits of any discovery and the costs of divergence determine the best approach to innovation (Almirall \& Casadesus-Masanell, 2010; Chiang \& Hung, 2010; Spithoven, Clarysse, \& Knockaert, 2010; Yu \& Hang, 2010; Hutter, Hautz, Fueller, Mueller, \& Matzler, 2011; Lichtenthaler; 2011; Laursen \& Salter, 2014).

\section{Cluster 3 ( $n=33$ articles): Open Innovation and Knowledge}

Historically, companies have invested in R\&D departments to drive innovation and provide the bases for sustainable growth. The most open model of innovation proposes that companies recognise that not every good idea emerges from within the organisational domain and not all the good ideas generated by the organisation are susceptible for successful commercialisation (Chesbrough, 2003b; Chesbrough \& Crowther, 2006; Piller \& Walcher, 2006; West \& Gallagher, 2006; Dodgson, Gann, \& Salter, 2006; Henkel, 2006; Fetterhoff \& Voelkel, 2006 ).

The business innovation model is vital to maintaining open innovation. External technological partners enable open commercial models to undergo increasingly widespread implementation. One important mechanism for innovating the business model arises from establishing co-development relationships. The appropriate characteristics of these relations vary in accordance with the relational context. In order to maintain co-development relationships, there is a need to carefully define the business objectives and align the commercial models of each company. Furthermore, attention needs to focus on determining whether the various $R \& D$ capacities are essential, critical or contextual (Chesbrough, 2007; Chesbrough \& Appleyard, 2007; Fleming \& Waguespack, 2007; Terwiesch \& Xu, 2008). 
Companies may open their innovation processes up across two dimensions. While inbound open innovation refers to the acquisition of external technology in open exploration processes, outbound open innovation describes the external transfer of technology in open exploration processes. Earlier research on open innovation focused upon the entrance dynamics while the dimension of outputs gets relatively overlooked. The level of technological turbulence, the rate of transactions and the competitive intensity of technology markets strengthen the positive effects of outbound open innovation on company performance (Lichtenthaler, 2009; Lichtenthaler \& Ernst, 2009; Kohler, Matzler \& Fueller, 2009; Fichter, 2009).

There is also great importance in analysing the processes by which a company might adopt an open innovation model, including: inter-organisational networks, organisational structures, evaluation processes and knowledge management systems, the means for managing and stimulating changes (Dahlander \& Gann, 2010; Jeppesen \& Lakhani, 2010; Chiaroni, Chiesa, \& Frattini, 2010; Belussi, Sammarra, \& Sedita, 2010; Bianchi, Campodall'Orto, Frattini, \& Vercesi, 2010; van de Vrande, Vanhaverbeke \& Gassmann (2010); van de Vrande et al., 2010; Wallin \& von Krogh, 2010). Online communities also constitute a virtual means of organisation in which knowledge collaboration may occur on unparalleled scales and scopes. One of the fundamental characteristics of online communities that provide such collaboration is their fluidity.

This fluidity encapsulates a dynamic flow of resources both within and beyond the community - resources such as passion, time, identity, the social disembodiment of ideas, socially ambiguous identities and temporary convergence. With each particular resource, there comes a negative and positive consequence and creating a tension that fluctuates in accordance with changes to the resources (Faraj, Jarvenpaa, \& Majchrzak, 2011; Chiaroni, Chiesa, \& Frattini, 2011; Mention, 2011; Chesbrough, 2011). There is a common understanding of the management of knowledge as implementing information technology systems that enable the processes of creating, sharing and learning of knowledge.

The management of knowledge, however, at the company level is undergoing rapid change. There is the advancing trend to make recourse to social software for this management as this provides open and cheap alternatives to traditional means of implementation (von Krogh, 2012; S. M. Lee, Hwang, \& Choi, 2012; Ballell et al., 2013; Spithoven, Vanhaverbeke, \& Roijakkers, 2013; Franzoni \& Sauermann, 2014; Felin \& Zenger, 2014). 


\section{Cluster 4 ( $n=20$ articles): Open Innovation and Innovation Spillovers}

The deployment of purveyors of specialist knowledge as sources of information for manufacturing and service company innovation activities represents an increasingly important option. These purveyors of specialist knowledge are consultancies, private research organisations and science based entities (thus, universities and research laboratories). Their involvement may reflect in cooperative innovation agreements or as informal sources of information.

Recourse to purveyors of specialist knowledge tends to complement both the internal innovation activities ongoing at companies and other external sources of knowledge (Lichtenthaler \& Ernst, 2006; Chesbrough \& Schwartz, 2007; Tether \& Tajar; 2008; Fueller, Matzler, \& Hoppe, 2008; West \& O’Mahony, 2008; Lichtenthaler \& Lichtenthaler, 2009; Ebner, Leimeister \& Krcmar, 2009). Another increasingly key focus of attention involves the study of innovation network management within the scope of fostering organisational innovation activities (Gassmann, Enkel, \& Chesbrough, 2010; Rampersad, Quester, \& Troshani, 2010; Schoenmakers \& Duysters, 2010; Gronlund, Sjodin, \& Frishammar, 2010).

Strategic networks, as collaborative organisations in networks and the virtual communities of clients, contain great potential as factors for the co-creation of value and co-innovation. Both consider the network structures as a source for the joint creation of value and open innovation through access to new abilities, knowledge, markets and technologies, sharing risks and integrating complementary competences. The strategic business networks are, in turn, active entities that continually adapt to their surrounding environment in order to enhance their capacities to respond to business opportunities in the short term and, therefore, enable their business ecosystems to keep up with the pace of the dynamics prevailing in its industry alongside the changing preferences of clients.

The co-creation of value represents the new trend in open business models that seek to integrate the competences of organisations and draw upon the individual preferences of clients in networked and community formations for co-creation close to the level of the value of the products, services and experiences launched upon the market (Romero \& Molina, 2011; Love, Roper, \& Bryson, 2011; Fueller, Hutter, \& Faullant, 2011; Boudreau, 2012; Chaston \& Scott, 2012; Berchicci, 2013; Alexy, George, \& Salter, 2013; Majchrzak \& Malhotra (2013). 


\section{Cluster 5 ( $n=14$ articles): Open Innovation Management}

Industrial innovation is becoming increasingly open, demanding changes in the ways that companies go about managing innovation. The external sources of knowledge have come to the fore while external challenges to the market are also requiring greater commitment. This has complicated the evaluation of technological projects in their initial stages that generally involve technological uncertainties and significant markets. In these circumstances, companies need to "play poker", as well as chess.

Errors in measurement (false positive, false negatives) are probable in addition to erroneous judgements about the commercial potential of projects during their early phases. The majority of company policies consciously limit the "false positives" in their commercial evaluations of projects but few companies even bother taking measures to manage the risks of "false negatives" (Chesbrough; 2004; Kirschbaum, 2005; von Hippel \& von Krogh, 2006) In the past, the majority of industrial companies concentrated on applying their technological resources to their own products and services. In conjunction with the trend towards open innovation, many companies have recently begun actively licensing technology.

These companies correspondingly consider the licensing of technology as a strategic activity, which may extend to every type of technological resource and that reaches beyond marginal activities of commercialising residual technologies (Lichtenthaler \& Ernst, 2007; Hurmelinna, Kylaeheiko, \& Jauhiainen, 2007; Cooper, 2008). Currently, there is broad awareness as to open innovation and its relevance to corporate R\&D. The implications and trends underpinning open innovation receive active discussion across its strategic, organisational and behavioural perspectives in terms of the knowledge, legal and business consequences as well as its economic implications.

This special question seeks to advance $R \& D$, innovation and the management perspective of technology, based on past and current studies on the field and putting forward future orientations. There is thus a rising level of need to gain a full understanding of how and where open innovation might aggregate value through intensive knowledge based processes (Enkel, Gassmann, \& Chesbrough, 2009; Di Gangi \& Wasko, 2009; Rohrbeck, Hoelzle, \& Gemuenden, 2009; Alexy, Criscuolo, \& Salter, 2009). Companies are increasingly adopting open models of innovation which 
depend on technological alliances to complement and reinforce their internal innovation efforts.

The diversity in the portfolio of technological alliances has returned a positive indirect impact on financial returns through boosting performances in terms of product innovation. However, the literature also reports the effects of the direct costs of diversity in technological alliances portfolios on such financial performance (Faems, de Visser, Andries, \& Van Looy, 2010; Sieg, Wallin, \& von Krogh, 2010; Chen, Chen, \& Vanhaverbeke, 2011; Garriga, von Krogh, \& Spaeth, 2013)

\section{Cluster 6 ( $n=3$ articles): Open Innovation and Technology}

The commercialisation of external technology, hence, the commercialisation of technological knowledge exclusively or in addition to its application within the company, has spread to become a broader trend (Lichtenthaler (2007). Furthermore, depending on the business sector, it has thus become to a greater or lesser extent easier to identify these sources of external technology. Nevertheless, understanding how the sector seeks out sources of knowledge and external technology represents a fundamental dimension (Ili, Albers, \& Miller, 2010). While the economic returns on property rights have faded, there are limitations to economies of scale and the capital requirements are low level despite those stemming from the effects of the experience curve, distribution and the costs of change still remaining. Therefore, the returns from difficult to imitate resources and reputation remain intact (Reed, Storrud-Barnes, \& Jessup, 2012).

\section{Final Considerations}

This research project sought to map and analyse the intellectual knowledge on open innovation. To this end, we carried out a bibliometric study with recourse to co-citations before then applying cluster and factorial analysis to ensure the identification and classification of the various theoretical perspectives within the field of open innovation. While consisting of a somewhat fragmented literature, scientific production on this field has risen over recent years that have registered not only the highest number of publications but also citations. The analysis and systematisation of the articles returned by the search resulted in six clusters or lines of research that concentrate the main subjects discussed within the scope of open innovation, among which there is also a clear interdependence of subject matter: the open innovation concept, open innovation 
and networks, open innovation and knowledge, open innovation and innovation spillovers, open innovation management, and open innovation and technology.

There is broad acceptance that innovation constitutes one of the most important drivers behind economic growth within the currently prevailing knowledge era (Stough, 2003). Porter and Stern (2001) defend that the vitality of innovation depends upon the national capacity of innovation. This capacity above all incorporates the potential of each country, at the political and economic levels, to produce flows of commercially relevant innovations.

The present study reports evidence as to how knowledge, technology and networks, spillovers of innovation and innovation management constitute determinant factors for organisational changes as regards open innovation processes. The findings obtained from the literature highlight non-linear relationships and fundamentally due to the different forms of measurements applied to open innovation and alongside the different contexts in which these studies take place. This study holds direct implications for the literature on open innovation, above all due to its identification of those subjects that underwent research, their respective contributions and main conclusions. This thus provides a map of the literature that enables the scientific community to better understand the main subjects under debate, the discoveries, the uncertainties and the future agenda.

Irrespective of the contributions identified, this study holds its own limitations, in particular its recourse to only one database for selecting the articles then subject to study. While the WoS stands out as an international benchmark reference database, the gathering of articles from other databases and sources might supply other analytical perspectives on open innovation related phenomena.

\section{Bibliography}

Alexy, O., Criscuolo, P., \& Salter, A. (2009). Does IP Strategy Have to Cripple Open Innovation? MIT SLOAN MANAGEMENT REVIEW, 51(1), 71-77.

Alexy, O., George, G., \& Salter, A. J. (2013). CUI BONO? THE SELECTIVE REVEALING OF KNOWLEDGE AND ITS IMPLICATIONS FOR INNOVATIVE ACTIVITY. ACADEMY OF MANAGEMENT REVIEW, 38(2), 270-291. http://doi.org/10.5465/amr.2011.0193

Allarakhia, M., \& Steven, W. (2011). Managing knowledge assets under conditions of radical change: The case of the pharmaceutical industry. TECHNOVATION, 31(2-3), 105-117. http://doi.org/10.1016/j.technovation.2010.11.001

Almirall, E., \& Casadesus-Masanell, R. (2010). OPEN VERSUS CLOSED INNOVATION: A MODEL OF DISCOVERY AND DIVERGENCE. ACADEMY OF MANAGEMENT REVIEW, 35(1), $27-47$.

Baldwin, C., \& von Hippel, E. (2011). Modeling a Paradigm Shift: From Producer Innovation to User and Open Collaborative Innovation. ORGANIZATION SCIENCE, 22(6), 1399-1417. 
http://doi.org/10.1287/orsc.1100.0618

Ballell, L., Bates, R. H., Young, R. J., Alvarez-Gomez, D., Alvarez-Ruiz, E., Barroso, V., ... Cammack, N. (2013). Fueling Open-Source Drug Discovery: 177 Small-Molecule Leads against Tuberculosis. CHEMMEDCHEM, 8(2), 313-321. http://doi.org/10.1002/cmdc.201200428

Belussi, F., Sammarra, A., \& Sedita, S. R. (2010). Learning at the boundaries in an 'Open Regional Innovation System $\{$ ' $\}$ : A focus on firms' innovation strategies in the Emilia Romagna life science industry. RESEARCH POLICY, 39(6), 710-721. http://doi.org/10.1016/j.respol.2010.01.014

Berchicci, L. (2013). Towards an open R\&D system: Internal R\&D investment, external knowledge acquisition and innovative performance. RESEARCH POLICY, 42(1), 117-127. http://doi.org/10.1016/j.respol.2012.04.017

Bianchi, M., Campodall'Orto, S., Frattini, F., \& Vercesi, P. (2010). Enabling open innovation in smalland medium-sized enterprises: how to find alternative applications for your technologies. $R \& D$ MANAGEMENT, 40(4), 414-431.

Bianchi, M., Cavaliere, A., Chiaroni, D., Frattini, F., \& Chiesa, V. (2011). Organisational modes for Open Innovation in the bio-pharmaceutical industry: An exploratory analysis. TECHNOVATION, 31(1, SI), 22-33. http://doi.org/10.1016/j.technovation.2010.03.002

Boudreau, K. J. (2012). Let a Thousand Flowers Bloom? An Early Look at Large Numbers of Software App Developers and Patterns of Innovation. ORGANIZATION SCIENCE, 23(5, SI), 1409-1427. http://doi.org/10.1287/orsc.1110.0678

Chaston, I., \& Scott, G. J. (2012). Entrepreneurship and open innovation in an emerging economy. Management Decision, 50(7), 1161-1177. http://doi.org/10.1108/00251741211246941

Chen, J., Chen, Y., \& Vanhaverbeke, W. (2011). The influence of scope, depth, and orientation of external technology sources on the innovative performance of Chinese firms. TECHNOVATION, 31(8), 362-373. http://doi.org/10.1016/j.technovation.2011.03.002

Chesbrough, H. W. (2003a). The era of open innovation. MIT SLOAN MANAGEMENT REVIEW, 44(3), 35-41.

Chesbrough, H. W. (2003b). The logic of open innovation: Managing intellectual property. CALIFORNIA MANAGEMENT REVIEW, 45(3), 33+.

Chesbrough, H. W. (2004). Managing open innovation. RESEARCH-TECHNOLOGY MANAGEMENT, $47(1), 23-26$.

Chesbrough, H. W. (2007). Why companies should have open business models. MIT SLOAN MANAGEMENT REVIEW, 48(2), 22+.

Chesbrough, H. W. (2011). Bringing Open Innovation to Services. MIT SLOAN MANAGEMENT REVIEW, 52(2), 85+.

Chesbrough, H. W. (2012). Open Innovation Where We've Been and Where We're Going. RESEARCHTECHNOLOGY MANAGEMENT, 55(4, SI), 20-27. http://doi.org/10.5437/08956308X5504085

Chesbrough, H. W., \& Appleyard, M. M. (2007). Open innovation and strategy. CALIFORNIA MANAGEMENT REVIEW, 50(1), 57+.

Chesbrough, H. W., \& Crowther, A. K. (2006). Beyond high tech: early adopters of open innovation in other industries. $R \& D$ MANAGEMENT, 36(3), 229-236. http://doi.org/10.1111/j.14679310.2006.00428.x

Chesbrough, H. W., \& Schwartz, K. (2007). Innovating business models with co-development partnerships. RESEARCH-TECHNOLOGY MANAGEMENT, 50(1), 55-59.

Chiang, Y.-H., \& Hung, K.-P. (2010). Exploring open search strategies and perceived innovation performance from the perspective of inter-organizational knowledge flows. $R \& D$ MANAGEMENT, 40(3), 292-299.

Chiaroni, D., Chiesa, V., \& Frattini, F. (2010). Unravelling the process from Closed to Open Innovation: evidence from mature, asset-intensive industries. $R \& D M A N A G E M E N T, 40(3), 222-245$.

Chiaroni, D., Chiesa, V., \& Frattini, F. (2011). The Open Innovation Journey: How firms dynamically implement the emerging innovation management paradigm. TECHNOVATION, 31(1, SI), 34-43. http://doi.org/10.1016/j.technovation.2009.08.007 
Christensen, J. F., Olesen, M. H., \& Kjaer, J. S. (2005). The industrial dynamics of Open Innovation Evidence from the transformation of consumer electronics. RESEARCH POLICY, 34(10), 1533 1549. http://doi.org/10.1016/j.respol.2005.07.002

Cooke, P. (2005). Regionally asymmetric knowledge capabilities and open innovation exploring 'Globalisation 2' - A new model of industry organisation. RESEARCH POLICY, 34(8), 1128-1149. http://doi.org/10.1016/j.respol.2004.12.005

Cooper, R. G. (2008). Perspective: The Stage-Gate (R) idea-to-launch process-update, what's new, and NexGen systems. JOURNAL OF PRODUCT INNOVATION MANAGEMENT, 25(3), 213-232. http://doi.org/10.1111/j.1540-5885.2008.00296.x

Dahlander, L., \& Gann, D. M. (2010). How open is innovation? Research Policy, 39(6), 699-709. http://doi.org/10.1016/j.respol.2010.01.013

Di Gangi, P. M., \& Wasko, M. (2009). Steal my idea! Organizational adoption of user innovations from a user innovation community: A case study of Dell IdeaStorm. DECISION SUPPORT SYSTEMS, 48(1, SI), 303-312. http://doi.org/10.1016/j.dss.2009.04.004

Di Guardo, M. C., \& Harrigan, K. R. (2012). Mapping research on strategic alliances and innovation: a co-citation analysis. The Journal of Technology Transfer, 37, 789-811.

Dittrich, K., \& Duysters, G. (2007). Networking as a means to strategy change: The case of open innovation in mobile telephony. JOURNAL OF PRODUCT INNOVATION MANAGEMENT, 24(6), 510-521. http://doi.org/10.1111/j.1540-5885.2007.00268.x

Dodgson, M., Gann, D., \& Salter, A. (2006). The role of technology in the shift towards open innovation: the case of Procter \& Gamble. $R \& D$ MANAGEMENT, 36(3), 333-346. http://doi.org/10.1111/j.1467-9310.2006.00429.x

Drechsler, W., \& Natter, M. (2012). Understanding a firm's openness decisions in innovation. JOURNAL OF BUSINESS RESEARCH, 65(3), 438-445. http://doi.org/10.1016/j.jbusres.2011.11.003

Ebner, W., Leimeister, J. M., \& Krcmar, H. (2009). Community engineering for innovations: the ideas competition as a method to nurture a virtual community for innovations. $R \& D M A N A G E M E N T$, 39(4), 342-356.

Enkel, E., \& Gassmann, O. (2010). Creative imitation: exploring the case of cross-industry innovation. $R$ \& D MANAGEMENT, 40(3), 256-270.

Enkel, E., Gassmann, O., \& Chesbrough, H. W. (2009). Open R \& D and open innovation : exploring the phenomenon. $R \& D$ Management, 39(4), 311-316.

Faems, D., de Visser, M., Andries, P., \& Van Looy, B. (2010). Technology Alliance Portfolios and Financial Performance: Value-Enhancing and Cost-Increasing Effects of Open Innovation. JOURNAL OF PRODUCT INNOVATION MANAGEMENT, 27(6), 785-796. http://doi.org/10.1111/j.1540-5885.2010.00752.x

Faraj, S., Jarvenpaa, S. L., \& Majchrzak, A. (2011). Knowledge Collaboration in Online Communities. ORGANIZATION SCIENCE, 22(5), 1224-1239. http://doi.org/10.1287/orsc.1100.0614

Felin, T., \& Zenger, T. R. (2014). Closed or open innovation? Problem solving and the governance choice. RESEARCH POLICY, 43(5, SI), 914-925. http://doi.org/10.1016/j.respol.2013.09.006

Fetterhoff, T. J., \& Voelkel, D. (2006). Managing open innovation in biotechnology. RESEARCHTECHNOLOGY MANAGEMENT, 49(3), 14-18.

Fichter, K. (2009). Innovation communities: the role of networks of promotors in Open Innovation. $R \&$ D MANAGEMENT, 39(4), 357-371.

Fleming, L., \& Waguespack, D. M. (2007). Brokerage, boundary spanning, and leadership in open innovation communities. ORGANIZATION SCIENCE, 18(2), 165-180. http://doi.org/10.1287/orsc. 1060.0242

Franzoni, C., \& Sauermann, H. (2014). Crowd science: The organization of scientific research in open collaborative projects. RESEARCH POLICY, 43(1), 1-20. http://doi.org/10.1016/j.respol.2013.07.005

Fueller, J., Hutter, K., \& Faullant, R. (2011). Why co-creation experience matters? Creative experience and its impact on the quantity and quality of creative contributions. $R \& D M A N A G E M E N T, 41(3)$, 259-273. 
Fueller, J., Matzler, K., \& Hoppe, M. (2008). Brand community members as a source of innovation. JOURNAL OF PRODUCT INNOVATION MANAGEMENT, 25(6), 608-619. http://doi.org/10.1111/j.1540-5885.2008.00325.x

Garriga, H., von Krogh, G., \& Spaeth, S. (2013). HOW CONSTRAINTS AND KNOWLEDGE IMPACT OPEN INNOVATION. STRATEGIC MANAGEMENT JOURNAL, 34(9), 1134-1144. http://doi.org/10.1002/smj.2049

Gassmann, O., Enkel, E., \& Chesbrough, H. (2010). The future of open innovation. $R \& D$ MANAGEMENT, 40(3), 213-221.

Gronlund, J., Sjodin, D. R., \& Frishammar, J. (2010). Open Innovation and the Stage-Gate Process: A REVISED MODEL FOR NEW PRODUCT DEVELOPMENT. CALIFORNIA MANAGEMENT REVIEW, 52(3), 106+.

Hawkins, D. T. (1977). Unconventional Uses of On-line Information Retrieval Systems : On-line Bibliometric Studies. Journal of the American Society for Information Science, 28(1), 13-18.

Henkel, J. (2006). Selective revealing in open innovation processes: The case of embedded Linux. RESEARCH POLICY, 35(7), 953-969. http://doi.org/10.1016/j.respol.2006.04.010

Huizingh, E. K. R. E. (2011). Open innovation: State of the art and future perspectives. TECHNOVATION, 31(1, SI), 2-9. http://doi.org/10.1016/j.technovation.2010.10.002

Hurmelinna, P., Kylaeheiko, K., \& Jauhiainen, T. (2007). The Janus face of the appropriability regime in the protection of innovations: Theoretical re-appraisal and empirical analysis. TECHNOVATION, 27(3), 133-144. http://doi.org/10.1016/j.technovation.2005.09.011

Hutter, K., Hautz, J., Fueller, J., Mueller, J., \& Matzler, K. (2011). Communitition: The Tension between Competition and Collaboration in Community-Based Design Contests. CREATIVITY AND INNOVATION MANAGEMENT, 20(1), 3-21. http://doi.org/10.1111/j.1467-8691.2011.00589.x

Ili, S., Albers, A., \& Miller, S. (2010). Open innovation in the automotive industry. $R \& D$ MANAGEMENT, 40(3), 246-255.

Jacobides, M. G., \& Billinger, S. (2006). Designing the boundaries of the firm: From “make, buy, or ally\{"\} to the dynamic benefits of vertical architecture. ORGANIZATION SCIENCE, 17(2), 249261. http://doi.org/10.1287/orsc.1050.0167

Jeppesen, L. B., \& Lakhani, K. R. (2010). Marginality and Problem-Solving Effectiveness in Broadcast Search. ORGANIZATION SCIENCE, 21(5), 1016-1033. http://doi.org/10.1287/orsc.1090.0491

Keupp, M. M., \& Gassmann, O. (2009). Determinants and archetype users of open innovation. $R \& D$ MANAGEMENT, 39(4), 331-341.

Kirschbaum, R. (2005). Open innovation in practice. RESEARCH-TECHNOLOGY MANAGEMENT, 48(4), 24-28.

Kohler, T., Matzler, K., \& Fueller, J. (2009). Avatar-based innovation: Using virtual worlds for realworld innovation. TECHNOVATION, 29(6-7), 395-407. http://doi.org/10.1016/j.technovation.2008.11.004

Laursen, K., \& Salter, A. J. (2014). The paradox of openness: Appropriability, external search and collaboration. RESEARCH POLICY, 43(5, SI), 867-878. http://doi.org/10.1016/j.respol.2013.10.004

Lee, S. M., Hwang, T., \& Choi, D. (2012). Open innovation in the public sector of leading countries. MANAGEMENT DECISION, 50(1-2), 147-162. http://doi.org/10.1108/00251741211194921

Lee, S., Park, G., Yoon, B., \& Park, J. (2010). Open innovation in SMEs-An intermediated network model. RESEARCH POLICY, 39(2), 290-300. http://doi.org/10.1016/j.respol.2009.12.009

Leimeister, J. M., Huber, M., Bretschneider, U., \& Krcmar, H. (2009). Leveraging Crowdsourcing: Activation-Supporting Components for IT-Based Ideas Competition. JOURNAL OF MANAGEMENT INFORMATION SYSTEMS, 26(1), 197-224. http://doi.org/10.2753/MIS07421222260108

Li, Y.-R. (2009). The technological roadmap of Cisco's business ecosystem. TECHNOVATION, 29(5), 379-386. http://doi.org/10.1016/j.technovation.2009.01.007

Lichtenthaler, U. (2007). The drivers of technology licensing: An industry comparison. CALIFORNIA MANAGEMENT REVIEW, 49(4), 67+. 
Lichtenthaler, U. (2008). Open innovation in practice: An analysis of strategic approaches to technology transactions. IEEE TRANSACTIONS ON ENGINEERING MANAGEMENT, 55(1), 148-157. http://doi.org/10.1109/TEM.2007.912932

Lichtenthaler, U. (2009). Outbound open innovation and its effect on firm performance: examining environmental influences. $R \& D$ MANAGEMENT, 39(4), 317-330.

Lichtenthaler, U. (2011). Open Innovation: Past Research, Current Debates, and Future Directions. ACADEMY OF MANAGEMENT PERSPECTIVES, 25(1), 75-93.

Lichtenthaler, U., \& Ernst, H. (2006). Attitudes to externally organising knowledge management tasks: a review, reconsideration and extension of the NIH syndrome. $R \& D$ MANAGEMENT, 36(4), $367-$ 386. http://doi.org/10.1111/j.1467-9310.2006.00443.x

Lichtenthaler, U., \& Ernst, H. (2007). External technology commercialization in large firms: results of a quantitative benchmarking study. $R \& D$ MANAGEMENT, 37(5), 383-397. http://doi.org/10.1111/j.1467-9310.2007.00487.x

Lichtenthaler, U., \& Ernst, H. (2009). Opening up the innovation process : the role of technology aggressiveness. $R \& D$ Management, 39(1), 38-53.

Lichtenthaler, U., \& Lichtenthaler, E. (2009). A Capability-Based Framework for Open Innovation: Complementing Absorptive Capacity. Journal of Management Studies, 46(8), 1315-1338. http://doi.org/10.1111/j.1467-6486.2009.00854.x

Love, J. H., Roper, S., \& Bryson, J. R. (2011). Openness, knowledge, innovation and growth in UK business services. RESEARCH POLICY, 40(10), 1438-1452. http://doi.org/10.1016/j.respol.2011.05.016

Majchrzak, A., \& Malhotra, A. (2013). Towards an information systems perspective and research agenda on crowdsourcing for innovation. JOURNAL OF STRATEGIC INFORMATION SYSTEMS, 22(4), 257-268. http://doi.org/10.1016/j.jsis.2013.07.004

Mention, A.-L. (2011). Co-operation and co-opetition as open innovation practices in the service sector: Which influence on innovation novelty? TECHNOVATION, 31(1, SI), 44-53. http://doi.org/10.1016/j.technovation.2010.08.002

Mortara, L., \& Minshall, T. (2011). How do large multinational companies implement open innovation? TECHNOVATION, 31(10-11), 586-597. http://doi.org/10.1016/j.technovation.2011.05.002

Mutschke, P., Mayr, P., Schaer, P., \& Sure, Y. (2011). Science models as value-added services for scholarly information systems. Scientometrics, 89(1), 349-364. http://doi.org/10.1007/s11192-0110430-x

Osareh, F. (1996). Bibliometrics, Citation Analysis and Co-Citation Analysis: A Review of Literature I. Libri, 46(3), 149-158.

Parida, V., Westerberg, M., \& Frishammar, J. (2012). Inbound Open Innovation Activities in High-Tech SMEs: The Impact on Innovation Performance. JOURNAL OF SMALL BUSINESS MANAGEMENT, 50(2, SI), 283-309. http://doi.org/10.1111/j.1540-627X.2012.00354.x

Piller, F. T., \& Walcher, D. (2006). Toolkits for idea competitions: a novel method to integrate users in new product development. $R \& D$ MANAGEMENT, 36(3), 307-318. http://doi.org/10.1111/j.14679310.2006.00432.x

Rampersad, G., Quester, P., \& Troshani, I. (2010). Managing innovation networks: Exploratory evidence from ICT, biotechnology and nanotechnology networks. INDUSTRIAL MARKETING MANAGEMENT, 39(5, SI), 793-805. http://doi.org/10.1016/j.indmarman.2009.07.002

Reed, R., Storrud-Barnes, S., \& Jessup, L. (2012). How open innovation affects the drivers of competitive advantage Trading the benefits of IP creation and ownership for free invention. MANAGEMENT DECISION, 50(1-2), 58-73. http://doi.org/10.1108/00251741211194877

Rohrbeck, R., Hoelzle, K., \& Gemuenden, H. G. (2009). Opening up for competitive advantage - How Deutsche Telekom creates an open innovation ecosystem. $R \& D$ MANAGEMENT, 39(4), 420-430.

Romero, D., \& Molina, A. (2011). Collaborative networked organisations and customer communities: value co-creation and co-innovation in the networking era. PRODUCTION PLANNING \& CONTROL, 22(5-6, SI), 447-472. http://doi.org/10.1080/09537287.2010.536619

Rost, K. (2011). The strength of strong ties in the creation of innovation. RESEARCH POLICY, 40(4), 
588-604. http://doi.org/10.1016/j.respol.2010.12.001

Schoenmakers, W., \& Duysters, G. (2010). The technological origins of radical inventions. RESEARCH POLICY, 39(8), 1051-1059. http://doi.org/10.1016/j.respol.2010.05.013

Sieg, J. H., Wallin, M. W., \& von Krogh, G. (2010). Managerial challenges in open innovation: a study of innovation intermediation in the chemical industry. $R \& D M A N A G E M E N T, 40(3), 281-291$.

Small, H. (1973). Co-citation in the Scientific Literature : A New Measure of the Relationship Between Two Documents. Journal of the American Society for Information Science, 24, 265-269.

Smith, L. C. (1981). Citation analysis. Bibliometrics, Library Trends, 30(1), (Summer).

Spithoven, A., Clarysse, B., \& Knockaert, M. (2010). Building absorptive capacity to organise inbound open innovation in traditional industries. TECHNOVATION, 30(2), 130-141. http://doi.org/10.1016/j.technovation.2009.08.004

Spithoven, A., Clarysse, B., \& Knockaert, M. (2011). Building absorptive capacity to organise inbound open innovation in traditional industries. TECHNOVATION, 31(1, SI), 10-21. http://doi.org/10.1016/j.technovation.2010.10.003

Spithoven, A., Vanhaverbeke, W., \& Roijakkers, N. (2013). Open innovation practices in SMEs and large enterprises. SMALL BUSINESS ECONOMICS, 41(3), 537-562. http://doi.org/10.1007/s11187-0129453-9

Stang, P. E., Ryan, P. B., Racoosin, J. A., Overhage, J. M., Hartzema, A. G., Reich, C., .. Woodcock, J. (2010). Advancing the Science for Active Surveillance: Rationale and Design for the Observational Medical Outcomes Partnership. ANNALS OF INTERNAL MEDICINE, 153(9), 600-606. http://doi.org/10.7326/0003-4819-153-9-201011020-00010

Terwiesch, C., \& Xu, Y. (2008). Innovation contests, open innovation, and multiagent problem solving. MANAGEMENT SCIENCE, 54(9), 1529-1543. http://doi.org/10.1287/mnsc.1080.0884

Tether, B. S., \& Tajar, A. (2008). Beyond industry-university links: Sourcing knowledge for innovation from consultants, private research organisations and the public science-base. RESEARCH POLICY, 37(6-7), 1079-1095. http://doi.org/10.1016/j.respol.2008.04.003

Thomsom Reuters. (2008). Using bibliometrics: A guide to evaluating research performance with citation data (Retrieved). Retrieved from http://ip-science.thomsonreuters.com/m/pdfs/325133_thomson.pdf

van de Vrande, V., de Jong, J. P. J., Vanhaverbeke, W., \& de Rochemont, M. (2009). Open innovation in SMEs: Trends, motives and management challenges. TECHNOVATION, 29(6-7), 423-437. http://doi.org/10.1016/j.technovation.2008.10.001

van de Vrande, V., Vanhaverbeke, W., \& Gassmann, O. (2010). Broadening the scope of open innovation: past research, current state and future directions. INTERNATIONAL JOURNAL OF TECHNOLOGY MANAGEMENT, 52(3-4), 221-235.

von Hippel, E., \& von Krogh, G. (2006). Free revealing and the private-collective model for innovation incentives. $R \& D$ MANAGEMENT, 36(3), 295-306. http://doi.org/10.1111/j.14679310.2006.00435.x

von Krogh, G. (2012). How does social software change knowledge management? Toward a strategic research agenda. JOURNAL OF STRATEGIC INFORMATION SYSTEMS, 21(2, SI), 154-164. http://doi.org/10.1016/j.jsis.2012.04.003

Wallin, M. W., \& von Krogh, G. (2010). Organizing for Open Innovation: Focus on the Integration of Knowledge. ORGANIZATIONAL DYNAMICS, 39(2, SI), 145-154. http://doi.org/10.1016/j.orgdyn.2010.01.010

West, J., \& Gallagher, S. (2006). Challenges of open innovation: the paradox of firm investment in opensource software. $R \& D$ MANAGEMENT, 36(3), 319-331. http://doi.org/10.1111/j.14679310.2006.00436.x

West, J., \& O’Mahony, S. (2008). The Role of Participation Architecture in Growing Sponsored Open Source Communities. INDUSTRY AND INNOVATION, 15(2), 145-168. http://doi.org/10.1080/13662710801970142

White, H. D., \& McCain, K. W. (1998). Visualizing a discipline: An author co-citation analysis of information science, 1972-1995. Journal of the American Society for Information Science, 49(4), $327-355$. 
Yu, D., \& Hang, C. C. (2010). A Reflective Review of Disruptive Innovation Theory. INTERNATIONAL JOURNAL OF MANAGEMENT REVIEWS, 12(4), 435-452. http://doi.org/10.1111/j.14682370.2009.00272.x

Zitt, M., \& Bassecoulard, E. (1994). Development of a method for detection and trend analysis of research fronts built by lexical or cocitation analysis. Scientometrics, 30, 333-351.

\section{Appendix}

\section{Table 1 - Articles used in co-citation analysis}

\begin{tabular}{|c|c|c|}
\hline \# & Article & Citations \\
\hline \multicolumn{3}{|c|}{ Cluster 1} \\
\hline 1 & Chesbrough (2003a) & 778 \\
\hline 4 & van de Vrande, de Jong, Vanhaverbeke, \& de Rochemont (2009) & 429 \\
\hline 6 & Huizingh (2011) & 372 \\
\hline 9 & S. Lee, Park, Yoon, \& Park (2010) & 276 \\
\hline 17 & Christensen, Olesen, \& Kjaer (2005) & 213 \\
\hline 22 & Baldwin \& von Hippel (2011) & 177 \\
\hline 28 & Leimeister, Huber, Bretschneider, \& Krcmar (2009) & 162 \\
\hline 29 & Cooke (2005) & 154 \\
\hline 30 & Stang et al. (2010) & 150 \\
\hline 36 & Parida, Westerberg, \& Frishammar (2012) & 115 \\
\hline 38 & Spithoven, Clarysse, \& Knockaert (2011) & 113 \\
\hline 39 & Bianchi, Cavaliere, Chiaroni, Frattini, \& Chiesa (2011) & 111 \\
\hline 56 & Keupp \& Gassmann (2009) & 88 \\
\hline 66 & Enkel \& Gassmann (2010) & 72 \\
\hline 67 & Rost (2011) & 70 \\
\hline 82 & $\operatorname{Li}(2009)$ & 63 \\
\hline 85 & Chesbrough (2012) & 62 \\
\hline 87 & Drechsler \& Natter (2012) & 57 \\
\hline 91 & Mortara \& Minshall (2011) & 55 \\
\hline 99 & Allarakhia \& Steven (2011) & 50 \\
\hline \multicolumn{3}{|c|}{ Cluster 2} \\
\hline 18 & Lichtenthaler (2008) & 194 \\
\hline 19 & Dittrich \& Duysters (2007) & 189 \\
\hline 25 & Lichtenthaler (2011) & 170 \\
\hline 33 & Almirall \& Casadesus-Masanell (2010) & 135 \\
\hline 37 & Jacobides \& Billinger (2006) & 115 \\
\hline 46 & Chiang \& Hung (2010) & 100 \\
\hline 47 & Spithoven, Clarysse, \& Knockaert (2010) & 100 \\
\hline 54 & Laursen \& Salter (2014) & 89 \\
\hline 74 & Yu \& Hang (2010) & 67 \\
\hline 77 & Hutter, Hautz, Fueller, Mueller, \& Matzler (2011) & 66 \\
\hline \multicolumn{3}{|c|}{ Cluster 3} \\
\hline 2 & Dahlander \& Gann (2010) & 543 \\
\hline 3 & Chesbrough \& Crowther (2006) & 488 \\
\hline 10 & Chesbrough \& Appleyard (2007) & 266 \\
\hline 11 & Jeppesen \& Lakhani (2010) & 249 \\
\hline 12 & Piller \& Walcher (2006) & 240 \\
\hline 13 & West \& Gallagher (2006) & 239 \\
\hline 14 & Dodgson, Gann, \& Salter (2006) & 229 \\
\hline 16 & Henkel (2006) & 220 \\
\hline
\end{tabular}




\begin{tabular}{|c|c|c|}
\hline 20 & Terwiesch \& Xu (2008) & 188 \\
\hline 21 & Fleming \& Waguespack (2007) & 182 \\
\hline 23 & Chesbrough (2007) & 176 \\
\hline 24 & Chesbrough (2003b) & 171 \\
\hline 26 & Faraj, Jarvenpaa, \& Majchrzak (2011) & 168 \\
\hline 40 & Lichtenthaler (2009) & 107 \\
\hline 43 & Chiaroni, Chiesa, \& Frattini (2011) & 103 \\
\hline 44 & Ballell et al. (2013) & 102 \\
\hline 49 & von Krogh (2012) & 97 \\
\hline 51 & Kohler, Matzler, \& Fueller (2009) & 93 \\
\hline 55 & Mention (2011) & 88 \\
\hline 59 & Chesbrough (2011) & 81 \\
\hline 60 & Chiaroni, Chiesa, \& Frattini (2010) & 81 \\
\hline 62 & Franzoni \& Sauermann (2014) & 74 \\
\hline 71 & S. M. Lee, Hwang, \& Choi (2012) & 68 \\
\hline 72 & Lichtenthaler \& Ernst (2009) & 68 \\
\hline 76 & Belussi, Sammarra, \& Sedita (2010) & 67 \\
\hline 86 & Bianchi, Campodall'Orto, Frattini, \& Vercesi (2010) & 59 \\
\hline 88 & Fichter (2009) & 57 \\
\hline 89 & Felin \& Zenger (2014) & 55 \\
\hline 90 & Spithoven, Vanhaverbeke, \& Roijakkers (2013) & 55 \\
\hline 93 & van de Vrande, Vanhaverbeke, \& Gassmann (2010) & 54 \\
\hline 94 & van de Vrande et al. (2010) & 53 \\
\hline 95 & Fetterhoff \& Voelkel (2006) & 53 \\
\hline 100 & Wallin \& von K33rogh (2010) & 50 \\
\hline \multicolumn{3}{|c|}{ Cluster 4} \\
\hline 7 & Gassmann, Enkel, \& Chesbrough (2010) & 319 \\
\hline 15 & Lichtenthaler \& Lichtenthaler (2009) & 224 \\
\hline 27 & Tether \& Tajar (2008) & 166 \\
\hline 31 & Fueller, Matzler, \& Hoppe (2008) & 141 \\
\hline 34 & Chesbrough \& Schwartz (2007) & 134 \\
\hline 35 & Chesbrough \& Schwartz (2007) & 120 \\
\hline 41 & Ebner, Leimeister, \& Krcmar (2009) & 105 \\
\hline 48 & West \& O’Mahony (2008) & 98 \\
\hline 50 & Berchicci (2013) & 95 \\
\hline 52 & Lichtenthaler \& Ernst (2006) & 92 \\
\hline 64 & Boudreau (2012) & 72 \\
\hline 65 & Romero \& Molina (2011) & 72 \\
\hline 68 & Love, Roper, \& Bryson (2011) & 69 \\
\hline 69 & Rampersad, Quester, \& Troshani (2010) & 69 \\
\hline 75 & Schoenmakers \& Duysters (2010) & 67 \\
\hline 78 & (Fueller, Hutter, \& Faullant, 2011) & 64 \\
\hline 80 & Alexy, George, \& Salter, 2013) & 63 \\
\hline 81 & Gronlund, Sjodin, \& Frishammar (2010) & 63 \\
\hline 83 & Majchrzak \& Malhotra (2013) & 62 \\
\hline 98 & Chaston \& Scott (2012) & 50 \\
\hline \multicolumn{3}{|c|}{ Cluster 5} \\
\hline 5 & Enkel, Gassmann, \& Chesbrough (2009) & 394 \\
\hline 8 & Cooper (2008) & 296 \\
\hline 32 & Chesbrough (2004) & 140 \\
\hline 42 & Faems, de Visser, Andries, \& Van Looy (2010) & 104 \\
\hline 45 & Di Gangi \& Wasko (2009) & 102 \\
\hline 53 & von Hippel \& von Krogh (2006) & 92 \\
\hline 57 & Kirschbaum (2005) & 83 \\
\hline 58 & Chen, Chen, \& Vanhaverbeke (2011) & 82 \\
\hline 61 & Rohrbeck, Hoelzle, \& Gemuenden (2009) & 81 \\
\hline 63 & Sieg, Wallin, \& von Krogh (2010) & 74 \\
\hline 70 & Lichtenthaler \& Ernst (2007) & 69 \\
\hline 79 & Hurmelinna, Kylaeheiko, \& Jauhiainen (2007) & 64 \\
\hline
\end{tabular}




\begin{tabular}{|c|c|c|}
\hline 84 & Garriga, von Krogh, \& Spaeth (2013) & 62 \\
\hline 92 & Alexy, Criscuolo, \& Salter (2009) & 55 \\
\hline \multicolumn{3}{|c|}{ Cluster 6 } \\
\hline 73 & Lichtenthaler (2007) & 68 \\
\hline 96 & Ili, Albers, \& Miller (2010) & 52 \\
\hline 97 & Reed, Storrud-Barnes, \& Jessup (2012) \\
\hline
\end{tabular}

